\title{
Maintainer and Restorer Identification and Conversion of Good Combiner Inbreds into New CMS Lines of Sunflower (Helianthus annuus L.)
}

\author{
H.P. Meena ${ }^{1} *$ H.D. Pushpa ${ }^{1}$ and M.K. Ghodke ${ }^{2}$ \\ ${ }^{1}$ ICAR-Indian Institute of Oilseeds Research, Rajendranagar, Hyderabad, India \\ ${ }^{2}$ Oilseeds Research Station, Latur, Maharashtra, India \\ *Corresponding author
}

\begin{tabular}{|l|}
\hline Key w or d s \\
Sunflower, \\
Maintainers, \\
Restorers, New \\
CMS \\
\hline Article Info \\
\hline Accepted: \\
18 January 2019 \\
Available Online: \\
10 February 2019 \\
\hline \hline
\end{tabular}

\section{A B S T R A C T}

Diversification of parental base in any hybrid breeding programme is an important step to sustain the crop. Fifty seven uniform and stable gene pool materials and exotic collection of economic importance of sunflower were crossed with six cytoplasmic male sterile lines of PET-1 background in a Line $\mathrm{x}$ Tester fashion to study their maintainer or restorer reaction in a randomized block design in two replications. The inbredGP ${ }_{6}-990$ acted as restores for all six CMS lines. While inbreds, $\mathrm{GP}_{6}-217, \mathrm{GP}_{6}-219, \mathrm{GP}_{6^{-}} 351, \mathrm{GP}_{6^{-}}-400, \mathrm{GP}_{6^{-}}$ 435, $\mathrm{GP}_{6}-969, \mathrm{GP}_{6}-976, \mathrm{GP}_{6}-1153, \mathrm{GP}_{4}-363$ and $\mathrm{GP}_{4}-548$ were found common maintainers for all six CMS sources. Inbred $\mathrm{GP}_{6}-212$ behaved as restorer for most of the CMS lines but behaved as maintainer for CMS-852A. While, inbred $\mathrm{GP}_{6}-106$ behaved as restorer for CMS-852A and behaved as segregating/partial restorer for CMS-234A, CMS17A, and CMS-7-1A. It showed that these CMS lines have different cytoplasm or are different at molecular levels. Selective inbreds were analyzed for combining ability and ten of the identified good combiner and agronomically superior maintainers were converted into new CMS lines. Newly developed lines, CMS-1001A, CMS-1003A, CMS-1004A, CMS-1006A and CMS-1008A had oil content $>36.0 \%$ compared to other CMS lines and highest oil content $(39.6 \%)$ was reported in CMS-1006A coupled with short stature (91.2 $\mathrm{cm})$. These newly developed CMS lines will be utilized in heterosis breeding programme for development of promising hybrids. The identification of new restorers to the good combiner CMS sources assembled should receive priority for hybrid synthesis.

\section{Introduction}

Commercial cultivation of sunflower (Helianthus annuus L.) in India started with open pollinated varieties. In sunflower, hybrids are superior over open-pollinated cultivars in terms of yield, self-fertility and resistance to diseases (Miller, 1987). The discovery of cytoplasmic male sterility (Leclercq, 1969) and fertility restoration genes by Kinman (1970)in sunflower has resulted in the development of hybrids for commercial cultivation. Till date 21 varieties/populations and 35 hybrids were released in India (Dudhe and Sujatha, 2016). However, the success in heterosis programme is largely dependent on the development of inbreds of wide genetic base (Giriraj, 1998). In general, inbreds with high combining ability and per se performance are either 
converted into CMS lines or fertility restorer lines for their future use in breeding programmes. Development of hybrids with diverse cytoplasmic background has been one of the major priority. Nevertheless, frequent use of the same sterile cytoplasm increases the genetic vulnerability of the present sunflower hybrids to diseases and pests. In order to minimize such a risk, new sources of cytoplasmic male sterility and corresponding fertility restorers are essential to increase the genetic diversity of the commercial hybrids. It is therefore essential to identify the effective restorers for each of the sources and elucidate the inheritance pattern of fertility restoration in the respective fertility restorer lines. It is also being that the yield levels have stagnated in sunflower with the presently used them in heterosis breeding to develop hybrids with high heterosis is necessary. In India different diseases are the main limiting factor in the production of sunflower and they cause poor realization of genetic yield potential of sunflower hybrid. Downy mildew is an economically significant disease. The results of sick plot revealed that the disease reduces sunflower seed yield up to $89 \%$ and negatively affects the other traits (Ghodke et al., 2016). The present study was undertaken to identify effective restorer lines to the CMS sources. In view of this limitation, an attempt was made at the ICAR-Indian Institute of Oilseeds Research, Rajendranagar, Hyderabad, to explore the possibilities of finding out good restorers and maintainers based on sterility and fertility reactions in the different CMS background and convert high oil content and promising good combiner maintainer inbreds into new CMS through backcross approach after screening for downy mildew in sick plot.

\section{Materials and Methods}

A total of fifty seven gene pool and exotic collection lines of economic importance of sunflower consisting of $12 \mathrm{inbreds}$ from gene pool $4\left(\mathrm{GP}_{4}\right)\left(\mathrm{GP} 4-288, \mathrm{GP}_{4}-346, \mathrm{GP}_{4}-363\right.$, $\mathrm{GP}_{4}-548, \mathrm{GP}_{4}-571, \mathrm{GP}_{4}-794, \mathrm{GP}_{4}-923, \mathrm{GP}_{4}-$ 1217, $\mathrm{GP}_{4}-1424, \mathrm{GP}_{4}-1435, \mathrm{GP}_{4}-1720$ and $\mathrm{GP}_{4}$-2927), 36 from gene pool $6\left(\mathrm{GP}_{6}-01\right.$, $\mathrm{GP}_{6}-73, \mathrm{GP}_{6} 212, \mathrm{GP}_{6}-106, \mathrm{GP}_{6-} 158, \mathrm{GP}_{6-} 160$, $\mathrm{GP}_{6-2} 217, \mathrm{GP}_{6-} 219, \mathrm{GP}_{6-} 234, \mathrm{GP}_{6-32} 32, \mathrm{GP}_{6-}$ 331， GP 6-351， GP $6-374 ， \mathrm{GP}_{6-} 400, \mathrm{GP}_{6-} 435$, $\mathrm{GP}_{6-} 527, \mathrm{GP}_{6-} 561, \mathrm{GP}_{6-} 794, \mathrm{GP}_{6-} 882, \mathrm{GP}_{6-}$ 884, GP 6 -896, GP $6-969, \mathrm{GP}_{6}-976, \mathrm{GP}_{6-} 990$, $\mathrm{GP}_{6-} 1108, \mathrm{GP}_{6-} 1153, \mathrm{GP}_{6-} 1233, \mathrm{GP}_{6-} 1242-1$, $\mathrm{GP}_{6-1} 1259, \quad \mathrm{GP}_{6-} 1301 ， \mathrm{GP}_{6-} 1350, \mathrm{GP}_{6-} 1419$, $\mathrm{GP}_{6-} 1468, \mathrm{GP}_{6-}-1477, \mathrm{GP}_{6-} 1493$ and $\mathrm{GP}_{6-} 1616$ ) and 9inbreds from exotic collection(EC601724, EC-601754, EC-601756, EC-601776, EC-601822, EC-601886, EC-602069, EC602033and EC-602022) were used for crossing with six CMS lines in Line $\mathrm{x}$ Tester design during the winter season of 2014. Before flowering (star bud stage) all the heads in the lines (CMS line) and testers $\left(\mathrm{GP}_{4}, \mathrm{GP}_{6}\right.$ and EC lines) were covered with cloth bags to prevent open pollination.

The pollen from the male lines was collected separately in Petri dishes with the help of camel hair brush, during morning hours (9:00 to 11:00 AM) and pollinated to each of the male sterile lines [CMS-234A (Bengaluru), CMS-17A (Bengaluru), CMS-852A (Bengaluru), CMS-7-1A (IIOR),CMS-2A (Latur)and CMS-10A (Latur)] separately and cloth bags were replaced immediately after pollination. The crossing was repeated (alternate day) till all the disc florets completed their opening. Each test hybrid was grown in a single row of $4.0 \mathrm{~m}$ with $60 \times 30$ $\mathrm{cm}$ row to row and plant to plant distances during the rainy season of 2015 at the ICARIndian Institute of Oilseeds Research, Rajendranagar, Hyderabad in randomized block design with two replications. All the agronomic practices (fertilizer application, earthing up, irrigation, insecticide spraying) were followed to raise a successful experimental crop. For fertility restoration studies, at the time of flowering, individual plants in each cross were observed for anther 
exertion and pollen shedding at anthesis stage and the crosses were categorized into male fertile, male sterile and partially fertile which correspond to restorer, maintainer and partial restorer behaviours of inbred lines, respectively. Combining ability of the inbreds were tested using method suggested by Singh and Choudhary (1976) during rainy season2015 and conversion programme was initiated and converted into new CMS lines through classical backcross method during rabi-2017-18. All the newly developed CMS lines and their counterpart also screened for downy mildew at Oilseeds Research Station, Latur, Maharashtra during rabi-2017-18 in sick plot. Observations were recorded for plant height $(\mathrm{cm})$, number of leaves/plant, head diameter $(\mathrm{cm})$, days to $50 \%$ flowering, days to maturity, oil content (\%), and seed yield per plant $(\mathrm{g})$.

\section{Results and Discussion}

The maintainer and restorer reaction of the inbreds for different CMS lines has been presented in table 1. In general, most of the inbreds tested behaved as maintainers for all CMS lines. Frequency of tested material as maintainers/restorer lines based on percent fertility restoration over different CMS sources was presented in table 2. From gene pool $\left(\mathrm{GP}_{6}\right)$ materials, only two inbreds $\left(\mathrm{GP}_{6}-\right.$ 990 and $\left.\mathrm{GP}_{6}-1051\right)$ behaved as restorers for all six CMS lines. While, only one inbred namely, EC-601848 out of 9 sunflower exotic collections could restore fertility for all the CMS lines. However, from gene pool $\left(\mathrm{GP}_{4}\right)$ materials none of the lines acted as restorer for all five CMS lines. $\mathrm{GP}_{4-571}$ inbred acted as restorer for CMS-852A and CMS-10A while acted as partial restorer for CMS-234A. Similarly, inbred $\mathrm{GP}_{6}-106$ also behaved as restorer for CMS-852A and CMS-2A while behaved as partial restorer for CMS-234A, CMS-17A and CMS-7-1A. The exact genetic basis of partial restoration is still unclear, but can be rectified with few more inbreeding cycles to obtain stable inbreds (Bhargavi and Vijayakumar, 2018). In this study we have found only 9 out of 57 lines tested behaved as restorers for all five CMS lines and produced fertile hybrids. Very recently, Meena et al. (2013) also reported lack of fertility restorer lines. Similar results were also reported by Reddy et al., (2008) and Satsish Chandar et al., (2011). Rukminidevi et al., (2006) and Sujatha and Vishnuvardhan Reddy (2008) also reported lack of fertility restorers other than PET-1. In contrary, Venkanna et al., (2006) results clearly indicate that majority of the tested inbreds behaved as restorers for the new CMS sources. The restorer for one CMS line behaved as maintainer for another line of the same CMS source, reconciling the diversity among CMS lines of the same source and between the different sources and possessing different mechanisms of male sterility. However, different authors reported different reasons for partial fertility like contamination of foreign pollen or the heterozygosity of the lines to restorer genes (Virupakashppa et al., 1991) or a possible contamination with the unknown pollen (Yogesh et al., 2007) or may be due to modifying effects of genes (DominguezGimenez and Fick, 1975). However, the inheritance of partial restoration is complex and highly dependent on environmental conditions (Wankhade et al., 2004).

\section{Common maintainers}

In this study, we have identified many common maintainers for different CMS lines (Table 1). From gene pool material inbreds, $\mathrm{GP}_{6-}-217, \mathrm{GP}_{6-} 219, \mathrm{GP}_{6^{-}} 351, \mathrm{GP}_{6^{-}} 400, \mathrm{GP}_{6^{-}}$ 435, GP $6_{-} 896, \mathrm{GP}_{6}-969, \mathrm{GP}_{6}-976, \mathrm{GP}_{6}-1108$, $\mathrm{GP}_{6}-1350, \mathrm{GP}_{6}-1468, \mathrm{GP}_{6}-1470, \mathrm{GP}_{6}-1477$, $\mathrm{GP}_{6}-1616, \mathrm{GP}_{4}-363, \mathrm{GP}_{4}-548, \mathrm{GP}_{4}-923$ and from exotic collection, EC-601724 and EC602022 were behaved as maintainers for all six CMS. Inbreds, $\mathrm{GP}_{4}-1435, \mathrm{GP}_{4}-2927, \mathrm{GP}_{6-}$ 
1301, were behaved as maintainer for some CMS and restorer for other CMS, this indicated that though CMS lines were different by cytoplasmic background, the fertility restoring gene could be same. Differential behavior of the lines for fertility/sterility reaction may be attributed to the genetic architecture especially the number of genes controlling and their interactions with cytoplasm in restoring fertility. The inbred lines restoring fertility to different forms of CMS sources were found to be most useful in practical breeding programmes.

Table.1 Identified maintainers and restorers for different CMS lines

\begin{tabular}{|c|c|c|c|c|c|c|c|}
\hline \multirow{2}{*}{$\begin{array}{l}\text { S. } \\
\text { No. }\end{array}$} & \multirow[t]{2}{*}{ Inbreds } & \multicolumn{6}{|c|}{ Different CMS of PET-1 Background } \\
\hline & & CMS-234A & CMS-17A & CMS-852A & CMS-7-1A & CMS-2A & CMS-10A \\
\hline 1 & $\mathrm{GP}_{6}-01$ & $\mathrm{R}$ & $\mathrm{R}$ & $\mathrm{R}$ & $\mathrm{R}$ & $\mathrm{R}$ & $\mathrm{M}$ \\
\hline 2 & $\mathrm{GP}_{6}-73$ & M & NT & NT & M & NT & NT \\
\hline 3 & $\mathrm{GP}_{6} 212$ & $\mathrm{R}$ & $\mathrm{R}$ & M & $\mathrm{R}$ & $\mathrm{R}$ & $\mathrm{R}$ \\
\hline 4 & $\mathrm{GP}_{6}-106$ & PR & PR & $\mathrm{R}$ & PR & $\mathrm{R}$ & M \\
\hline 5 & $\mathrm{GP}_{6} 158$ & M & NT & NT & PR & M & NT \\
\hline 6 & $\mathrm{GP}_{6} 160$ & M & NT & PR & M & M & M \\
\hline 7 & $\mathrm{GP}_{6} 217$ & M & M & M & M & M & M \\
\hline 8 & $\mathrm{GP}_{6} .219$ & M & M & NT & M & M & M \\
\hline 9 & $\mathrm{GP}_{6} .234$ & PR & NT & $\mathrm{R}$ & $\mathrm{R}$ & $\mathrm{R}$ & $\mathrm{R}$ \\
\hline 10 & $\mathrm{GP}_{6} .329$ & M & NT & M & PR & M & M \\
\hline 11 & $\mathrm{GP}_{6} .331$ & $\mathrm{R}$ & NT & $\mathrm{R}$ & $\mathrm{R}$ & $\mathrm{R}$ & $\mathrm{R}$ \\
\hline 12 & $\mathrm{GP}_{6} .351$ & M & NT & M & M & M & M \\
\hline 13 & $\mathrm{GP}_{6} \cdot 374$ & PR & NT & NT & M & NT & NT \\
\hline 14 & $\mathrm{GP}_{6} .400$ & M & NT & M & M & $\mathrm{M}$ & $\mathrm{M}$ \\
\hline 15 & $\mathrm{GP}_{6}-435$ & M & NT & M & M & M & M \\
\hline 16 & $\mathrm{GP}_{6} .527$ & M & NT & NT & M & NT & NT \\
\hline 17 & $\mathrm{GP}_{6} .561$ & PR & NT & $\mathrm{M}$ & NT & PR & $\mathrm{M}$ \\
\hline 18 & $\mathrm{GP}_{6-794}$ & M & NT & M & NT & NT & M \\
\hline 19 & $\mathrm{GP}_{6} 883$ & M & NT & M & $\mathrm{M}$ & $\mathrm{M}$ & NT \\
\hline 20 & $\mathrm{GP}_{6} .884$ & PR & NT & M & PR & M & PR \\
\hline 21 & $\mathrm{GP}_{6} 896$ & $\mathrm{M}$ & NT & M & $\mathrm{M}$ & M & $\mathrm{M}$ \\
\hline 22 & $\mathrm{GP}_{6} .969$ & M & M & M & NT & M & M \\
\hline 23 & $\mathrm{GP}_{6}-976$ & M & M & M & $\mathrm{M}$ & $\mathrm{M}$ & M \\
\hline 24 & $\mathrm{GP}_{6} .990$ & $\mathrm{R}$ & NT & $\mathrm{R}$ & $\mathrm{R}$ & $\mathrm{R}$ & $\mathrm{R}$ \\
\hline 25 & $\mathrm{GP}_{6-1} 1108$ & M & NT & M & M & M & M \\
\hline 26 & $\mathrm{GP}_{6-1} 1153$ & M & M & M & M & M & M \\
\hline 27 & $\mathrm{GP}_{6} 1233$ & PR & NT & PR & PR & M & M \\
\hline 28 & $\mathrm{GP}_{6-1242-1}$ & M & NT & $\mathrm{M}$ & M & PR & M \\
\hline 29 & $\mathrm{GP}_{6} 1259$ & $\mathrm{R}$ & NT & NT & NT & $\mathrm{R}$ & $\mathrm{R}$ \\
\hline 30 & $\mathrm{GP}_{6-1} 1301$ & M & NT & $\mathrm{M}$ & $\mathrm{R}$ & M & M \\
\hline 31 & $\mathrm{GP}_{6} 1350$ & M & NT & M & M & M & M \\
\hline 32 & $\mathrm{GP}_{6-1} 1419$ & M & NT & NT & M & NT & NT \\
\hline 33 & $\mathrm{GP}_{6-1} 1468$ & M & NT & M & M & M & M \\
\hline 34 & $\mathrm{GP}_{6-1} 1477$ & M & NT & M & M & M & M \\
\hline
\end{tabular}




\begin{tabular}{|c|c|c|c|c|c|c|c|}
\hline 35 & $\mathrm{GP}_{6-} 1493$ & $\mathrm{R}$ & NT & NT & PR & NT & NT \\
\hline 36 & $\mathrm{GP}_{6-} 1616$ & M & NT & M & M & $\mathrm{M}$ & M \\
\hline 37 & EC-601724 & $\mathrm{M}$ & $\mathrm{M}$ & M & $\mathrm{M}$ & M & $\mathrm{M}$ \\
\hline 38 & EC-601754 & $\mathrm{R}$ & NT & NT & $\mathrm{R}$ & NT & NT \\
\hline 39 & EC-601756 & PR & $\mathrm{R}$ & NT & $\mathrm{M}$ & NT & NT \\
\hline 40 & EC-601776 & $\mathrm{M}$ & NT & $\mathrm{R}$ & $\mathrm{R}$ & $\mathrm{R}$ & $\mathrm{R}$ \\
\hline 41 & EC-601822 & $\mathrm{M}$ & NT & NT & NT & $\mathrm{M}$ & $\mathrm{M}$ \\
\hline 42 & EC-601886 & M & NT & $\mathrm{R}$ & $\mathrm{R}$ & NT & $\mathrm{R}$ \\
\hline 43 & EC-602069 & $\mathrm{M}$ & NT & M & M & NT & M \\
\hline 44 & EC-602033 & $\mathrm{M}$ & NT & NT & $\mathrm{M}$ & NT & NT \\
\hline 45 & EC-602022 & $\mathrm{M}$ & NT & $\mathrm{M}$ & $\mathrm{M}$ & $\mathrm{M}$ & $\mathrm{M}$ \\
\hline 46 & $\mathrm{GP}_{4}-288$ & M & NT & PR & $\mathrm{M}$ & M & $\mathrm{M}$ \\
\hline 47 & $\mathrm{GP}_{4}-346$ & M & NT & NT & M & NT & NT \\
\hline 48 & $\mathrm{GP}_{4}-363$ & M & M & M & $\mathrm{M}$ & $\mathrm{M}$ & $\mathrm{M}$ \\
\hline 49 & $\mathrm{GP}_{4}-548$ & $\mathrm{M}$ & $\mathrm{M}$ & $\mathrm{M}$ & $\mathrm{M}$ & M & $\mathrm{M}$ \\
\hline 50 & $\mathrm{GP}_{4}-571$ & PR & $\mathrm{M}$ & $\mathrm{R}$ & $\mathrm{M}$ & $\mathrm{M}$ & $\mathrm{R}$ \\
\hline 51 & $\mathrm{GP}_{4}-794$ & $\mathrm{M}$ & NT & NT & $\mathrm{M}$ & $\mathrm{M}$ & $\mathrm{M}$ \\
\hline 52 & $\mathrm{GP}_{4}-923$ & M & NT & $\mathrm{M}$ & M & $\mathrm{M}$ & M \\
\hline 53 & $\mathrm{GP}_{4}-1217$ & $\mathrm{M}$ & $\mathrm{M}$ & $\mathrm{M}$ & $\mathrm{R}$ & $\mathrm{M}$ & $\mathrm{M}$ \\
\hline 54 & $\mathrm{GP}_{4}-1424$ & M & NT & PR & $\mathrm{M}$ & $\mathrm{M}$ & $\mathrm{M}$ \\
\hline 55 & $\mathrm{GP}_{4}-1435$ & $\mathrm{M}$ & $\mathrm{R}$ & NT & $\mathrm{M}$ & M & $\mathrm{M}$ \\
\hline 56 & $\mathrm{GP}_{4}-1720$ & $\mathrm{M}$ & $\mathrm{R}$ & M & NT & $\mathrm{M}$ & $\mathrm{M}$ \\
\hline 57 & $\mathrm{GP}_{4}-2927$ & M & $\mathrm{R}$ & $\mathrm{M}$ & $\mathrm{M}$ & $\mathrm{M}$ & $\mathrm{M}$ \\
\hline
\end{tabular}

Table.2 Frequency of tested material as maintainer/restorer lines based on percent fertility restoration over different CMS lines

\begin{tabular}{|l|c|c|c|c|c|c|c|}
\hline CMS line & $\begin{array}{c}\text { No. of } \\
\text { inbreds } \\
\text { tested }\end{array}$ & $\begin{array}{c}\text { Maintainer } \\
(\mathbf{M})\end{array}$ & $\begin{array}{c}\text { Percentage } \\
(\boldsymbol{\%})\end{array}$ & $\begin{array}{c}\text { Restorer } \\
(\mathbf{R})\end{array}$ & $\begin{array}{c}\text { Percentage } \\
(\boldsymbol{\%})\end{array}$ & $\begin{array}{c}\text { Partial } \\
\text { restorer } \\
(\mathbf{P R})\end{array}$ & $\begin{array}{c}\text { Percenta } \\
\text { ge }(\boldsymbol{\%})\end{array}$ \\
\hline CMS-234A & 57 & 42 & 73.68 & 07 & 12.28 & 08 & $\mathbf{1 4 . 0 3}$ \\
\hline CMS-17A & 17 & 10 & 58.82 & 06 & 35.29 & 01 & $\mathbf{5 . 8 8}$ \\
\hline CMS-852A & 42 & 30 & 71.42 & 08 & 19.04 & 04 & $\mathbf{9 . 5 2}$ \\
\hline CMS-7-1A & 51 & 35 & 68.62 & 10 & 19.60 & 06 & $\mathbf{1 1 . 7 6}$ \\
\hline CMS-2A & 45 & 35 & 77.77 & 08 & 17.77 & 02 & $\mathbf{4 . 4 4}$ \\
\hline CMS-10A & $\mathbf{4 6}$ & $\mathbf{3 7}$ & $\mathbf{8 0 . 4 3}$ & $\mathbf{0 8}$ & $\mathbf{1 7 . 3 9}$ & $\mathbf{0 1}$ & $\mathbf{2 . 1 7}$ \\
\hline
\end{tabular}

Table.3 Identified good general combiner inbreds for different traits

\begin{tabular}{|c|l|l|}
\hline S. No. & Inbreds & Good general combiners for \\
\hline $\mathbf{1}$ & $\begin{array}{l}\mathrm{GP}_{6} 217, \mathrm{GP}_{6}-883, \mathrm{GP}_{6}-932, \mathrm{GP} 6-969, \mathrm{GP}_{6}-976, \mathrm{GP}_{6}- \\
1153 \text { and } \mathrm{GP}_{6}-1423\end{array}$ & $\begin{array}{l}\text { High seed yield, plant height, } \\
\text { head diameter and high oil } \\
\text { content }\end{array}$ \\
\hline $\mathbf{2}$ & $\begin{array}{l}\mathrm{GP}_{6}-118, \mathrm{GP}_{6}-219, \mathrm{GP}_{6}-883, \mathrm{GP}_{6}-1108, \mathrm{EC}-602022, \\
\mathrm{EC}_{-} 601724 \text { and EC-601822 }\end{array}$ & $\begin{array}{l}\text { High seed yield and high oil } \\
\text { content }\end{array}$ \\
\hline
\end{tabular}


Table.4 Newly developed CMS lines and their reactions to downy powdery mildew diseases

\begin{tabular}{|c|c|c|c|c|c|c|c|c|c|}
\hline CMS No. & $\begin{array}{c}\text { Plant } \\
\text { height } \\
(\mathrm{cm})\end{array}$ & $\begin{array}{c}\text { No. of } \\
\text { leaves/plant }\end{array}$ & $\begin{array}{c}\text { Head } \\
\text { diameter } \\
(\mathrm{cm})\end{array}$ & $\begin{array}{c}\text { Days to } \\
50 \% \\
\text { flowering }\end{array}$ & $\begin{array}{l}\text { Days to } \\
\text { maturity }\end{array}$ & $\begin{array}{c}\text { Oil } \\
\text { content } \\
(\%)\end{array}$ & Generation & $\begin{array}{l}\text { Reaction } \\
\text { to downy } \\
\text { mildew }\end{array}$ & $\begin{array}{c}\text { Downy } \\
\text { mildew } \\
\text { incidence } \\
(\%)\end{array}$ \\
\hline DCMS-1001A & 141.0 & 26.0 & 13.0 & 65.0 & 96.0 & 37.58 & $\mathrm{BC}_{6}$ & $\mathrm{R}$ & 0.0 \\
\hline DCMS-1002A & 143.0 & 26.0 & 12.5 & 66.0 & 96.0 & 35.78 & $\mathrm{BC}_{6}$ & S & 25.3 \\
\hline DCMS-1003A & 129.1 & 26.0 & 13.0 & 69.0 & 99.0 & 37.34 & $\mathrm{BC}_{6}$ & $\mathrm{R}$ & 0.0 \\
\hline DCMS-1004A & 132.2 & 26.0 & 13.0 & 69.0 & 99.0 & 36.53 & $\mathrm{BC}_{6}$ & $\mathrm{R}$ & 0.0 \\
\hline DCMS-1005A & 138.7 & 26.0 & 12.2 & 66.0 & 95.0 & 34.28 & $\mathrm{BC}_{6}$ & $\mathrm{R}$ & 0.0 \\
\hline DCMS-1006A & 91.2 & 22.0 & 13.5 & 69.0 & 100.0 & 39.60 & $\mathrm{BC}_{6}$ & $\mathrm{R}$ & 0.0 \\
\hline DCMS-1007A & 118.4 & 22.0 & 10.6 & 64.0 & 93.0 & 32.67 & $\mathrm{BC}_{6}$ & S & 15.2 \\
\hline DCMS-1008A & 108.6 & 26.0 & 9.0 & 67.0 & 98.0 & 37.04 & $\mathrm{BC}_{6}$ & S & 20.6 \\
\hline DCMS-1009A & 136.2 & 26.0 & 13.8 & 66.0 & 96.0 & 33.76 & $\mathrm{BC}_{6}$ & $\mathrm{R}$ & 0.0 \\
\hline DCMS-1010A & 113.0 & 26.0 & 14.2 & 70.0 & 99.0 & 34.44 & $\mathrm{BC}_{6}$ & $\mathrm{R}$ & 0.0 \\
\hline
\end{tabular}


Frequency of maintainers, restorers and partial restorers

Frequency of tested material as maintainer, restorer and partial restorer/segregating types based on percent pollen fertility restoration were presented in table 2 . In the present study, 22.28 to $35.29 \%$ frequency of pollen fertility was reported for all the six CMS. The maximum percent pollen fertility $(35.29 \%)$ was observed for CMS-17A followed by CMS-7-1A (19.60\%), CMS-852A (19.06\%), CMS-2A (17.77\%), CMS-10A (17.39\%) and the minimum per cent pollen fertility $(12.28$ $\%$ ) was observed for CMS-234A. Maximum frequency $(80.43 \%)$ of tested material as maintainer was recorded for CMS-10A. Maximum per cent $(14.03 \%)$ frequency of partial restorer was observed for CMS-234A and minimum for CMS-2A (4.44\%). In this study, we noticed very high frequency of maintainers and very low frequency of fertility restoration for different CMS. Many authors from India and abroad were reported very low frequency of fertility restoration genes for different CMS sources (Meena and Prabakaran, 2016; Meena and Sujatha, 2013; Gouri Shankar et al.,2007; Virupakshappa et al., 1991) and concluded that hybrids could not be developed because of the nonavailability of effective restorers for these new CMS sources.

\section{Good combiner for various traits}

In hybrid breeding programme, the knowledge of combining ability of parental lines for desirable characteristics is essential for the conversion of good combining ability maintainers into new CMS lines and restorers for the development of new hybrids. Twenty eight inbreds tested for combining ability during kharif-2015. Seven inbreds namely, $\mathrm{GP}_{6}$ 217, $\mathrm{GP}_{6}-883, \mathrm{GP}_{6}-932$, GP6-969, $\mathrm{GP}_{6^{-}}$ 976, $\mathrm{GP}_{6}-1153$ and $\mathrm{GP}_{6}-1423$ were found good general combiners for high seed yield, plant height, head diameter and high oil content while, seven inbreds, $\mathrm{GP}_{6}-118, \mathrm{GP}_{6^{-}}$ 219, $\mathrm{GP}_{6}-883$, GP ${ }_{6}-1108$, EC-602022, EC601724 and EC-601822 were found good general combiners forhigh seed yield and high oil content (Table 3). The inbreds which were grouped as maintainers after testing for combining ability coupled with good agronomic performance could be used to develop either three way cross hybrids (Yogesh et al., 2007 and Jayalakshmi et al., 2001) or to develop new CMS lines (Sujatha, and Vishnuvardhan Reddy, 2008).

\section{Conversion of good combiner inbreds into different CMS background}

Diversification of parental base especially CMS base is the need of the hour in sunflower for development of high yielding hybrids along with resistant to biotic and abiotic stress. In this connection a total of ten good combiner and agronomically superior inbreds were converted into new CMS lines (DCMS1001A to DCMS-1010A). The morphological characters of these DCMS lines were given in the Table 4 . The days to $50 \%$ flowering varied from 64.0 to 70.0 days; plant height from 91.2 to $143.0 \mathrm{~cm}$; head diameter 9.0 to $14.2 \mathrm{~cm}$ and oil content 32.7 to $39.6 \%$. Newly developed lines, DCMS-1001A, DCMS1003A, DCMS-1004A, DCMS-1006A and DCMS-1008A had oil content >36.0\% compared to other CMS lines. Highest oil content $(39.6 \%)$ was reported in DCMS1006A coupled with short stature (91.2 $\mathrm{cm})$. These CMS lines were recommended for utilization in sunflower hybrid breeding programme.

\section{Screening for downy mildew}

All newly developed CMS lines along with their counterpart have been screened under sick plot for downy mildew disease at Oilseeds Research Station, Latur, Maharashtra during rabi-2017. Seven out of 
ten CMS lines viz., DCMS-1001A, DCMS1003A, DCMS-1004A, DCMS-1005A, DCMS-1006A, DCMS-1009 and DCMS1010A were found resistant to downy mildew under artificial screening while only three CMS namely, DCMS-1002A, DCMS-1007A and DCMS-1008A were found susceptible to downy mildew. Newly developed downy mildew resistant CMS lines can be used for development of downy mildew resistant hybrids.

In conclusion, local inbreds had more frequency of maintainers than restorer lines. Thus present study helped to identify a few effective restorers for available CMS lines, which can be exploited in future hybrid development or may be utilized in the development of new restorer lines. Newly developed CMS lines already using by ICARIIOR and AICRP centres in heterosis breeding programme for developing diverse hybrids with better heterosis and resistance to disease and insect pests.

\section{Acknowledgement}

The authors are thankful to the Director, ICAR-Indian Institute of Oilseeds Research, Rajendranagar, Hyderabad $500 \quad 030$ (Telangana) India, for providing financial support and the facilities to carry out this research work.

\section{References}

Bhargavi, H.A. and Vijayakumar, A.G. 2018. Studies on Fertility Restoration Using Newly Derived Restorers in Sunflower (Helianthus annuus L.). Int.J.Curr. Microbiol.App.Sci.7(1): 2131-2135.

Dominguez-Gimenez, J. and Fick, G.N. 1975. Fertility restoration of male sterile cytoplasm in wild sunflowers. Crop Science. 15: 724-726.
Dudhe, M.Y. and Sujatha, M. 2016. Four decades of sunflower genetic resources activities in India. In: Proceedings of 19th International Sunflower Conference, Edirne, Turkey, 2016. pp. 334.

Girriraj, K. 1998. In: Hybrid Sunflower Seed Production Technology. (Virupakshappa, K. et al., eds). Directorate of Oilseeds Research, Hyderabad, India Pp 10.

Ghodke M.K., Shirshikar, S.P. and Dudhe, M.Y. 2016. Sunflower breeding strategy for resistance to downy mildew disease in India. In Proc. of $19^{\text {th }}$ International Sunflower Conference, Edirne, Turkey. pp 792-798.

Gouri Shankar, V., Ganesh, M., Ranganatha, A.R.G., Suman, A. and Sridhar, V. 2007. Combining ability studies in diverse CMS sources in sunflower (Helianthus annuus L.). Indian Journal of Agricultural Research. 41(3): 171-176.

Jayalakshmi, V., Narendra, B. and Haritha, S. 2001. Maintainer/restorer identification for different CMS lines in sunflower (Helianthus annuus L.). Agric. Sci. Digest.21(4): 269-270.

Kinman, M.L. 1970. New development in USDA and state experimental station sunflower breeding programmes. Proc. of 4th International Sunflower Conference, Memphis, Tennessee, pp: 181-183.

Leclereq, P. 1969. Unesterilite cytoplasmique chezletournesol. Annals Amelior des Planet.19(2): 96-106.

Meena, C.R., Meena, H.P. and Sinha, B. 2013. Fertility restoration, combining ability effects and heterosis in sunflower (Helianthus annuus L.) using different CMS sources. Journal of Oilseeds Research.30(1): 60-64.

Meena, H.P. and Prabakaran, A.J. 2016. Identification of fertility restorers and maintainers in sunflower (Helianthus annuus L.) from gene pools and exotic material. Electronic Journal of Plant Breeding 7(3): 778-783. 
Meena, H.P. and Sujatha, M. 2013. Maintainer/restorer identification for different CMS lines in sunflower (Helianthus annuus $\quad$ L.). Journal of Oilseeds Research.30(2): 134-137.

Meena, H.P. Sujatha, M. and Varaprasad, K.S. 2013. Achievements and bottlenecks of heterosis breeding of sunflower (Helianthus annuus L.) in India. Indian Journal of Genetics. 73(2): 123-130.

Miller, J.F. 1987. Sunflower. In: Fehr, W.R. (Eds.), Principles of Cultivar Development, Macmillan Publishing Company, New York. Vol. 12: 626-668.

Reddy, C.V.C.M., Sinha, B., Reddy, A.V.V. and Reddy, Y.R. 2008. Maintenance of male sterility and fertility restoration in different CMS sources of sunflower (Helianthus annuus L.). Asian J. of Plant Sci. 7(8): 762-766.

Reddy, V.A., Trinadh Kumar, G., Sudheer Kumar, S. and Sokka Reddy, S. 2002. Inheritance of fertility restoration for different CMS sources in sunflower (Helianthus annuus L.). Journal of Oilseeds Research. 19: 178-180.

Rukminidevi, K., Ganesh, M. and Ranganatha, A.R.G. 2006. Inheritance of fertility restorers for new CMS sources in sunflower (Helianthus annuus L.). Journal of Oilseeds Research. 23(1): 4648.

Satish Chnadra, B., Sudheer Kumar, S., Ranganatha, A.R.G. and Dudhe, M.Y. 2011. Identification of restorers for diverse CMS sources in sunflower (Helianthus annuus L.). Journal of
Oilseeds Research. 28(1): 71-73.

Singh, R.K. and Chouduary, B.D. 1976. Biometrical Techniques in Genetics and Breeding. Int. Bioscience Publishers. Hisar. India.

Sujatha, M. and Vishnuvardhan Reddy, A. 2008. Identification of fertility restorers/maintainers in sunflower (Helianthus annuus L.). Journal of Oilseeds Research.25(2): 181-182.

Venkanna, V., Lokanadha Reddy, D. and Ranganatha, A.R.G. 2008. Identification of restorers and maintainers for different CMS sources in sunflower using new inbreds. Helia. 31(49): 65-70.

Virupakshappa, K., Seetharam, A. and Ravi Kumar, R.L. 1991. Maintainer and restorer behavior of some sunflower lines of new cytoplasmic male sterile sources. Journal of Oilseeds Research. 8: 195198.

Wankhade, R.R., Rajput, J.C., Halakude, I.S., Kulkarni, M.P., Sawarkar, N.W. and Dalvi, P.A. 2004. Identification of fertility restorers for CMS lines in sunflower (Helianthus annuus L.). Journal of Oilseeds Research.21: 156157.

Yogesh, L.N., Gangappa, E., Shadakshari, Y.G. and Manjunath, Y.S. 2007. Maintainer and restorer reaction of new sunflower inbred lines on PET 1 system with three nuclear backgrounds. National Seminar on Changing Global Vegetable Oils Scenario: Issues and Challenges before India, Jan. 29-31, pp.136-139.

\section{How to cite this article:}

Meena, H.P., H.D. Pushpa and Ghodke, M.K. 2019. Maintainer and Restorer Identification and Conversion of Good Combiner Inbreds into New CMS Lines of Sunflower (Helianthus annииs L.). Int.J.Curr.Microbiol.App.Sci. 8(02): 2210-2218. doi: https://doi.org/10.20546/ijcmas.2019.802.256 